\title{
Splenic Manifestation of Hairy Cell Leukemia
}

National Cancer Institute

\section{Source}

National Cancer Institute. Splenic Manifestation of Hairy Cell Leukemia. NCI Thesaurus.

Code C7301.

Infiltration and expansion of the red pulp of the spleen by hairy cell leukemia. 